\title{
Serological Reactivity and Identification of Immunoglobulin E-Binding Polypeptides of Ganoderma applanatum Crude Spore Cytoplasmic Extract in Puerto Rican Subjects
}

\author{
Frances Vilá-Héreter $^{a} \quad$ Félix E. Rivera-Marianib ${ }^{b}$ Benjamín Bolaños-Rosero ${ }^{a}$ \\ a Department of Microbiology, School of Medicine, University of Puerto Rico, Medical Sciences Campus, \\ San Juan, PR, and ' ${ }^{b}$ Department of Biology, Miami Dade College, Miami, FL, USA
}

\section{Keywords}

Allergy · Immunoglobulin E-binding polypeptides .

Serological reactivity · Ganoderma applanatum

\begin{abstract}
Background: The allergenic potential of Ganoderma applanatum basidiospores has been demonstrated previously in Puerto Rico. However, basidiomycete allergens are not available for inclusion in allergy diagnostic panels. Therefore, we sought to confirm allergic sensitization to G. applanatum crude spore cytoplasmic extract through reactivity in serological assays and detection of immunoglobulin $E$ ( $\lg E)$ binding polypeptides. Methods: Via an indirect ELISA, serological reactivity was compared between groups of individuals with different allergic profiles. Group $1(n=51)$ consisted of individuals with slgE to the allergens included in the diagnostic panels; group 2 ( $n=14$ ) comprised individuals with no slgE to the allergens tested; and group $3(n=22)$ included individuals with no allergic history. To visualize lgE-binding polypeptides, group 1 sera were examined via Western blotting (WB). Polypeptide bands with the highest reactivity were analyzed by mass spectrometry (MS) for putative identification. Results: The serological reactivity of group 1 was significantly higher than that of group 3 in an indirect ELISA $(p=0.03)$. Sixty-five percent of group 1 individuals showed
\end{abstract}

\section{KARGER}

(C) 2017 S. Karger AG, Basel

E-Mail karger@karger.com

www.karger.com/iaa reactivity to polypeptide bands in WB. Bands of 81 and 56 $\mathrm{kDa}$ had the highest reactivity proportions among the reactive sera, followed by a 45-kDa band. MS analysis of these 3 polypeptides suggests that they are basidiomycete-derived enzymes with aconitate hydratase, catalase, and enolase functions. Conclusions: G. applanatum spores have allergenic components recognized by Puerto Rican individuals, which could eventually be considered as markers in cases of fungal allergy and be included in diagnostic allergen panels in Puerto Rico and tropical regions. @ 2017 S. Karger AG, Basel

\section{Introduction}

Spores from basidiomycetes, such as Ganoderma applanatum, are prevalent in the atmosphere in many areas of the world and tropics, including Puerto Rico, where basidiospore allergy has been reported [1-10]. Contrary to mitosporic fungi, which produce spores asexually and are mostly composed of asexual states of ascomycetes (e.g., Aspergillus spp. and Penicillium spp.), the allergenic potential of basidiomycetes has been underestimated and only few allergens, such as Cop c 1-7 (Coprinus comatus), Psi c 1 and 2 (Psilocybe cubensis), and Sch c 1 (Schizophyllum commune), have been characterized [2, 11-13]. In 
addition, because of the difficulties encountered in collecting them on the field, and obtaining the necessary amount of spore material, extracts are not easily obtained [5-7]. As a result, basidiomyecetes are less studied and there is a lack of basidiospore extracts for allergy panels [5]. Considering that basidiospores constitute approximately two-thirds of the total fungal spores in outdoor air samples, these panels may not be representative of the composition of the Puerto Rican airborne fungal spores with allergenic potential [4].

Skin test reactivity to crude extracts of G. applanatum spores was previously demonstrated by our group among Puerto Rican allergic subjects [7]. G. applanatum had a higher reactivity (30 vs. $6 \%$ ) than all of the commercial extracts of mitogenic fungi tested (Penicillium spp., Aspergillus spp., Fusarium spp., Alternaria spp., and Chaetomium spp.). Furthermore, the level of sensitivity to $G$. applanatum and mites among asthmatic patients was $44 \%$ for both allergen extracts; the latter is an allergen source frequently associated with respiratory allergic diseases $[14,15]$. However, to confirm antibody reactivity against G. applanatum spore allergens and identify immunoreactive components, serological tests that detect these interactions are needed.

The current pilot study investigated the serological reactivity of Puerto Rican subjects to G. applanatum crude spore cytoplasmic extract (CSCE) using in vitro tests. An indirect ELISA was designed to detect immunoglobulin $\mathrm{E}$ (IgE) antibodies and compare serological reactivity among individuals with different allergic profiles. Furthermore, Western blot (WB) analysis was performed to identify IgE-binding polypeptides using sera from allergic individuals previously tested in the indirect ELISA. The polypeptide bands with the highest proportion of reactivity were analyzed and putatively identified by mass spectrometry (MS). Based on our previous findings and the high prevalence of respiratory diseases among Puerto Ricans, we expected to find a high serological reactivity rate to G. applanatum CSCE among the serum samples tested $[7,16,17]$.

\section{Materials and Methods}

\section{Spore Print Collection}

Fruiting bodies of G. applanatum were searched in forested and green areas of Puerto Rico. The spore prints were collected in the field with spore traps, which were replaced every 2-4 days. The spore traps consisted of sterile Petri dishes placed under the sporocarp of the fruiting body, secured with brite aluminum screening (Phifer, Tuscaloosa, AL, USA) and tacks. A coverslip was included in each spore trap to verify the purity of the spore print with mi- croscopy. Once collected, the dishes with the spore print deposits were placed in a desiccator for at least $24 \mathrm{~h}$ or until dry. The dry material was stored at $-80^{\circ} \mathrm{C}$ until extract preparation. If the spore print material showed any sign of contamination, it was discarded.

\section{CSCE Preparation}

The G. applanatum CSCE was prepared following the method described by Rivera-Mariani et al. [7] with few minor adjustments. Briefly, spore cytoplasmic proteins were extracted from a suspension consisting of $1 \mathrm{~g}$ of spore print material and $10 \mathrm{~mL}$ of ammonium bicarbonate buffer ( $0.125 \mathrm{M}, \mathrm{pH}$ 8.2; Fisher Scientific, Fair Lawn, NJ, USA) prepared with sterile pyrogen-free water (Baxter Healthcare, Deerfield, IL, USA). No protease inhibitors were added to the suspension; however, the preparation and handling of the extracts were carried out under conditions that minimize proteolysis. The homogenate was centrifuged at $208.5 \mathrm{~g}$ for $20 \mathrm{~min}$ at $4^{\circ} \mathrm{C}$ in a Sorvall RT6000B refrigerated centrifuge (Dupont, Wilmington, DE, USA). The resulting supernatant was centrifuged at 216,179.7 $\mathrm{g}$ for $1 \mathrm{~h}$ at $4^{\circ} \mathrm{C}$ in an Optima L-100 XP centrifuge (Beckman Coulter, Brea, CA, USA). The supernatant was filter-sterilized with a Nalgene 115 -mL filter unit $(0.45 \mu \mathrm{m}$; Nalge Nunc International, Rochester, NY, USA) and lyophilized for $24 \mathrm{~h}$ with an Edwards Modulyo freeze dryer (Edwards High Vacuum International, Crawley, UK). The resulting lyophilized solid was resuspended in $20 \%$ of the original volume with sterile pyrogen-free water, and the resuspended fractions were pooled and stored at $-80^{\circ} \mathrm{C}$ until use. This was the sample of CSCE used for the serological assays.

A small amount of CSCE was also prepared for skin prick test (SPT) administration. For this preparation, a portion of the lyophilized material was resuspended in $20 \%$ of the original volume with a solution containing $50 \%$ glycerol (VWR International, West Chester, PA, USA), 85 mM sodium chloride (Sigma-Aldrich, St. Louis, MO, USA), and $30 \mathrm{mM}$ sodium bicarbonate (AMRESCO, Solon, $\mathrm{OH}, \mathrm{USA}$ ), with subsequent pooling of the fractions. The saline part of the solution was prepared using sterile pyrogen-free water. The sterility of the CSCE pool for SPT administration was confirmed by inoculating a loopful of the extract on blood agar (Columbia blood agar base [Becton, Dickinson and Company, Sparks, MD, USA] and 5\% sheep red blood cells [Biolab, Bayamón, $\mathrm{PR}, \mathrm{USA}]$ ). The dish was left incubating at $25^{\circ} \mathrm{C}$ for 7 days, with no evidence of growth. This extract preparation was stored at $2-8^{\circ} \mathrm{C}$ until use.

\section{Determination of the Basidiospore Extract Protein}

Concentration

The protein concentration of the CSCE was determined using a DC Protein Assay Kit II (Bio-Rad, Hercules, CA, USA) according to manufacturer's instructions. The protein concentrations of the CSCE pools used in the serological assays ranged from 1.0 to 4.0 $\mathrm{mg} / \mathrm{mL}$. The protein concentration of the CSCE prepared for SPT administration was $1.3 \mathrm{mg} / \mathrm{mL}$. This protein concentration is in accordance with the recommendation from Greer Laboratories (Lenoir, NC, USA) for allergenic fungal extracts diluted in $50 \%$ glycerol to be used in SPT.

\section{Human Sera}

With the approval of the University of Puerto Rico - Medical Sciences Campus (UPR-MSC) Institutional Review Board (A9830113), human sera remnants were donated from the Toledo Clinical Laboratory (Arecibo, PR, USA) and other sera were col- 
lected from Puerto Rican volunteers from the UPR-MSC community without a history of allergic disease. The sera remnants donated from the clinical laboratory originated from individuals who had been tested for sIgE with RAST against various commercial allergens included in either one of two panels that consisted of respiratory allergens alone or respiratory and food allergens combined (Table 1); their clinical history was not available and the serum samples were not tested to the same battery of commercial allergens. Volunteers were adults from whom $20 \mathrm{~cm}^{3}$ of blood were obtained, and the serum was extracted in the laboratory. They had no symptoms of allergy, had never received treatment for allergy or its manifestations, and had no family history of allergic disease. The clinical history of the volunteers was not available.

\section{Selection of Controls}

A positive control who had sIgE to one or more fungal allergens was randomly selected from the donated serum remnants. This individual had sIgE to the following allergens: Alternaria tenuis, Aspergillus fumigatus, Cladosporium herbarum, Penicillium notatum, Dermatophagoides farinae, American cockroach, and rat epithelium. The sera remnant was further analyzed at a reference clinical laboratory for total IgE. The total IgE reported was $171 \mathrm{kU} / \mathrm{L}$, which is higher than normal IgE level for adults (as per http://www.questdiagnostics.com/). The random negative control (selected from the volunteer's sera) had no history of allergic disease and its total $\operatorname{IgE}$ was $4.20 \mathrm{kU} / \mathrm{L}$, which is a normal total IgE level (as per http://www. questdiagnostics.com/). In addition, SPT were performed on the negative control volunteer by a board-certified allergist from the UPR-MSC Allergy Clinics with a commercial allergen panel (Greer Laboratories) and the G. applanatum CSCE prepared in the laboratory for SPT administration. The commercial allergen extracts consisted of mitosporic fungi such as Penicillium spp., Aureobasidium spp., Alternaria spp., Cladosporium spp., Fusarium spp., Aspergillus spp., and Acremonium spp.; ascomycetes such as Chaetomium spp.; pollen of trees, Bermuda, Johnson, and Bahia; pet allergens such as dog and cat dander; cockroaches; mite allergens Der p and Der f; and positive (histamine $15 \mathrm{mg} / \mathrm{mL}$ ) and negative (glycerol phosphate-buffered saline [PBS]) controls. No positive results were recorded for the allergenic extracts tested, including CSCE.

\section{Indirect ELISA}

Indirect ELISA against CSCE was performed on 87 collected human sera following the protocol described by Figueroa-Santiago et al. [18] with minor adjustments. Reagents in the assay were optimized by checkerboard titration. Human sera were grouped as shown in Table 2. High-binding polystyrene microplates (Costar, Corning, NY, USA) were coated with $5 \mu \mathrm{g} / \mathrm{mL}$ of CSCE. Human sera and conjugated antibody (polyclonal goat anti-human IgE labeled with horseradish peroxidase, $1.0 \mathrm{mg} / \mathrm{mL}$; KPL, Gaithersburg, MD, USA) were used at dilutions of $1: 100$ and $1: 2,500$, respectively. Finally, substrate solution (10 $\mathrm{mg} o$-phenylenediamine dihydrochloride [Sigma-Aldrich] $+10 \mu \mathrm{L} 30 \% \mathrm{H}_{2} \mathrm{O}_{2}$ [Sigma-Aldrich] in $0.1 \mathrm{M}$ citrate-phosphate buffer, $\mathrm{pH}$ 5.0) was added to each well and the reaction was stopped with $10 \% \mathrm{HCl}$ (Sigma-Aldrich). The absorbance, at $490 \mathrm{~nm}\left(\mathrm{~A}_{490}\right)$, was immediately measured using a microplate reader (Model 680; Bio-Rad). Each determination was performed in duplicate, and the results were expressed as the mean $\mathrm{A}_{490}$ value for each determination. Positive and negative controls were included on each microplate.
Table 1. RAST commercial allergen panels previously tested on donated sera remnants by the reference clinical laboratory (Toledo Clinical Laboratory, Arecibo, PR, USA)

\begin{tabular}{|c|c|}
\hline Allergen panel & Allergens \\
\hline Respiratory & $\begin{array}{l}\text { Alternaria tenuis, American cockroach, } \\
\text { Aspergillus fumigatus, Cat dander/ } \\
\text { epithelium, chicken feathers, Cladosporium } \\
\text { herbarum, Dermatophagoides farinae, dog } \\
\text { epithelia, horse dander, mouse epithelium, } \\
\text { Penicillium notatum, and rat epithelium }\end{array}$ \\
\hline Respiratory/food & $\begin{array}{l}\text { Acacia, Alternaria tenuis, Aspergillus } \\
\text { fumigatus, Australian pine, Bermuda grass, } \\
\text { cat dander/epithelium, Cladosporium } \\
\text { herbarum, cockroach, corn, cow milk, } \\
\text { Dermatophagoides farinae, dog epithelia, egg, } \\
\text { English plantain, Fusarium moniliforme, } \\
\text { lamb's quarter, mango, Mucor racemosus, } \\
\text { Penicillium notatum, Phoma betae, queen } \\
\text { palm, rough pigweed, Western ragweed, } \\
\text { wheat }\end{array}$ \\
\hline
\end{tabular}

Each serum sample was tested for 1 of the panels, not both, and not all serum samples were tested for the same battery of allergens.

Table 2. Ganoderma applanatum crude spore cytoplasmic extract indirect ELISA sample groups

\begin{tabular}{|c|c|c|}
\hline $\begin{array}{l}\text { Serum samples with } \\
\text { different allergic profiles }\end{array}$ & Origin & $n$ \\
\hline $\begin{array}{l}\text { Group } 1^{\mathrm{a}} \text { : individuals }{ }^{\mathrm{c}} \text { with } \\
\text { sIgE reactive to } 1 \text { or more } \\
\text { allergens of the RAST } \\
\text { allergens tested }\end{array}$ & $\begin{array}{l}\text { Donated sera remnants } \\
\text { from the Toledo Clinical } \\
\text { Laboratory, Arecibo, PR, } \\
\text { USA }\end{array}$ & 51 \\
\hline $\begin{array}{l}\text { Group } 2^{\text {a: }} \text { individuals }{ }^{c} \text { with } \\
\text { no reactive sIgE to the RAST } \\
\text { allergens tested }\end{array}$ & $\begin{array}{l}\text { Donated sera remnants from } \\
\text { Toledo Clinical Laboratory, } \\
\text { Arecibo, PR, USA }\end{array}$ & 14 \\
\hline $\begin{array}{l}\text { Group } 3^{\text {b}} \text { : individuals }{ }^{c} \text { with } \\
\text { no previous history of allergic } \\
\text { disease based on self-reported } \\
\text { symptomatology }\end{array}$ & $\begin{array}{l}\text { Puerto Rican adult volunteers } \\
\text { from the University of Puerto } \\
\text { Rico - Medical Sciences } \\
\text { Campus community }\end{array}$ & 22 \\
\hline
\end{tabular}

Total

${ }^{a}$ Individuals in these groups were suspected of having allergic symptomatology due to the medical referral for sIgE testing. The serum samples were not tested for the same battery of commercial allergens. ${ }^{b}$ This group is not considered a negative control group, because no skin or serological tests were performed to confirm the absence of allergic sensitization. ${ }^{\mathrm{c}}$ The clinical history of these individuals is unknown. 
Sodium Dodecyl Sulfate-Polyacrylamide Gel Electrophoresis of CSCE, Silver Staining, and Protein Transfer

The protein components in CSCE were separated by molecular weight (MW) under denaturing conditions using 1-dimensional sodium dodecyl sulfate-polyacrylamide gel electrophoresis (SDSPAGE) following the method described by Laemmli [19]. The process was carried out on a $15 \%$ gel with $30 \mu \mathrm{g}$ of CSCE per lane under cold conditions at $200 \mathrm{~V}$ for $1 \mathrm{~h}$ and $45 \mathrm{~min}$. The resolved polypeptides were silver stained using a Silver Stain Plus Kit (BioRad) according to manufacturer's instructions or transferred to a nitrocellulose membrane $(0.45 \mu \mathrm{m}$; Bio-Rad $)$. For polypeptides being transferred, a stained (Rainbow) full-range MW marker (2.0 $\mathrm{mg} / \mathrm{mL}$; GE Healthcare Bio-Sciences, Piscataway, NJ, USA) was used for every CSCE sample. The transfer of resolved polypeptides was carried out under cold conditions in a Mini-PROTEAN Tetra Cell (Bio-Rad) in Tris-glycine buffer ( $\mathrm{pH}$ 8.0) containing $20 \%$ methanol at $200 \mathrm{~V}$ for $2 \mathrm{~h}$ and $10 \mathrm{~min}$.

\section{Western Blot}

Optimization of the assay was based on a compromise between band intensity in the positive control and less reactivity in the negative control, which was assisted by image-analysis performed for each sample and its corresponding marker using the open-source software Image $J^{\circledR}$ (National Institutes of Health). Density plots were produced in which the $x$ axis represents the distance along the membrane and the $y$ axis the averaged pixel intensity, represented as a peak. Each peak in the plot corresponds to a band in the membrane. Once the assay was optimized, WB were performed in duplicate for each serum in group 1 . After transference, the nitrocellulose membrane was cut into strips and blocked with $5 \%$ bovine serum albumin (AMRESCO) in PBS (0.01 M, pH 7.4) containing 0.05\% Tween 20 (PBST-20) for $1 \mathrm{~h}$ at room temperature (RT). Each strip was incubated overnight at $4^{\circ} \mathrm{C}$ with a serum sample diluted $1: 100$ in $3 \%$ bovine serum albumin prepared in PBST-20. After several washes with PBST-20, incubation with biotinylated polyclonal goat antihuman IgE antibody ( $0.5 \mathrm{mg} / \mathrm{mL}$ KPL), diluted 1:5,000 in blocking solution, followed for $4 \mathrm{~h}$ at RT. The strips were washed before incubating with avidin-horseradish peroxidase $(1.0 \mathrm{mg} / \mathrm{mL}$; SigmaAldrich), diluted 1:10,000 in blocking solution, for $20 \mathrm{~min}$ at RT. After washing, the substrate solution $\left(0.025 \mathrm{~g}\right.$ of $3,3^{\prime}$-diaminobenzidine [Sigma-Aldrich] $+50 \mu \mathrm{L}$ of $30 \% \mathrm{H}_{2} \mathrm{O}_{2}$ in $50 \mathrm{~mL} \mathrm{PBS} 0.01 \mathrm{M}, \mathrm{pH}$ 7.4) was added and left incubating for $30 \mathrm{~min}$ at RT. The solution was discarded and the reaction stopped with ultrapure water. Image analysis was performed with the software Image ${ }^{\circledR}$ as previously described to assist in the identification of IgE-binding polypeptides. Once the reactive bands had been identified, the marker was used to construct a reference standard curve from which the approximate MW of the reactive CSCE polypeptide bands was calculated based on their relative mobility in the membrane.

\section{Ultrafiltration of CSCE with Subsequent SDS-PAGE and Silver} Staining

Ultrafiltration of CSCE was performed to concentrate and separate the extract proteins with MW above $30 \mathrm{kDa}$, which were the most reactive in the WB. It was performed in an Amicon filter unit (Millipore, Beverly, MA, USA) using a regenerated cellulose membrane with a $30-\mathrm{kDa}$ cutoff (Millipore). The retentate, labeled as CSCE $>30$, was collected and the protein concentration determined $(3.2 \mathrm{mg} / \mathrm{mL})$ as previously described for the CSCE. SDSPAGE and silver staining for CSCE $>30$ were performed as de- scribed for the CSCE with a slight modification: the electrophoresis run time was increased to $2 \mathrm{~h}$ and $30 \mathrm{~min}$ to allow more separation between the polypeptide bands.

\section{Mass Spectrometry}

Bands corresponding to the three IgE-binding polypeptides identified to have the highest proportion of reactivity in the WB were excised from a silver stained gel of a CSCE > 30 SDS-PAGE and sent overnight to the Proteomics and Mass Spectrometry Facility at the Cornell University Institute of Biotechnology in Ithaca, NY, USA, for MS analysis and database search. The process consisted of an in-gel digestion with trypsin and extraction followed by nanoliquid chromatography coupled with a tandem MS (LC-MS/MS) analysis in an Orbitrap Elite (Thermo Fisher Scientific, Waltham, MA, USA) instrument. Since there is no current G. applanatum database available, the MS data was compared against the National Center for Biotechnology Information (NCBI) database using other Fungi taxonomies (http://www.ncbi.nlm.nih.gov/protein/). The search was done employing the Mascot database search engine using the following search setting: one missed cleavage site by trypsin allowed with fixed carboxamidomethyl modification of cysteine and variable modifications of methionine oxidation and deamidation of asparagine and glutamine residues. Mascot reports for each band were then interpreted for a putative protein identification.

\section{Statistical Analysis}

The statistical analysis was performed in $\mathrm{R}$ version 3.2.3 ( $\mathrm{R}$ Foundation for Statistical Computing, Vienna, Austria). Before performing a one-way ANOVA and Bonferroni's pairwise comparison test to determine mean differences in indirect ELISA $\mathrm{A}_{490}$ for individuals in groups 1,2, and 3, the normal distribution of $\mathrm{A}_{490}$ values and equal variances for each group was confirmed with a Shapiro-Wilk test and a Bartlett test, respectively. Fisher's exact test, with $95 \%$ CI, was performed to compare the proportion of reactive sera for each polypeptide band detected in the WB among group 1 sera reactive to CSCE. To evaluate if there was an association between indirect ELISA $\mathrm{A}_{490}$ and WB reactivity, group 1 sera were grouped as reactive (if reactive to one or more polypeptide bands in WB) versus nonreactive (not reactive to any polypeptide band in WB). Equal variances of the indirect ELISA $\mathrm{A}_{490}$ values between groups was confirmed with an $\mathrm{F}$ test, and normality in each group was determined by a Shapiro-Wilk test prior to performing a Student 2 -tailed $t$ test (assuming equal variance) to compare differences in mean indirect ELISA $\mathrm{A}_{490}$.

\section{Results}

\section{Indirect ELISA Reactivity against the Whole CSCE Differed between Groups 1 and 3}

To detect IgE antibodies and compare serological reactivities to CSCE, an indirect ELISA was performed on sera from individuals with 3 different allergic profiles (Fig. 1). The mean $\mathrm{A}_{490}$ was highest among individuals from group $1(0.5157 \pm 0.1637)$; the group 2 and group 3 mean $\mathrm{A}_{490}$ were $0.4963( \pm 0.1565)$ and $0.4162( \pm 0.1100)$, respectively. The ANOVA test showed a statistically sig- 


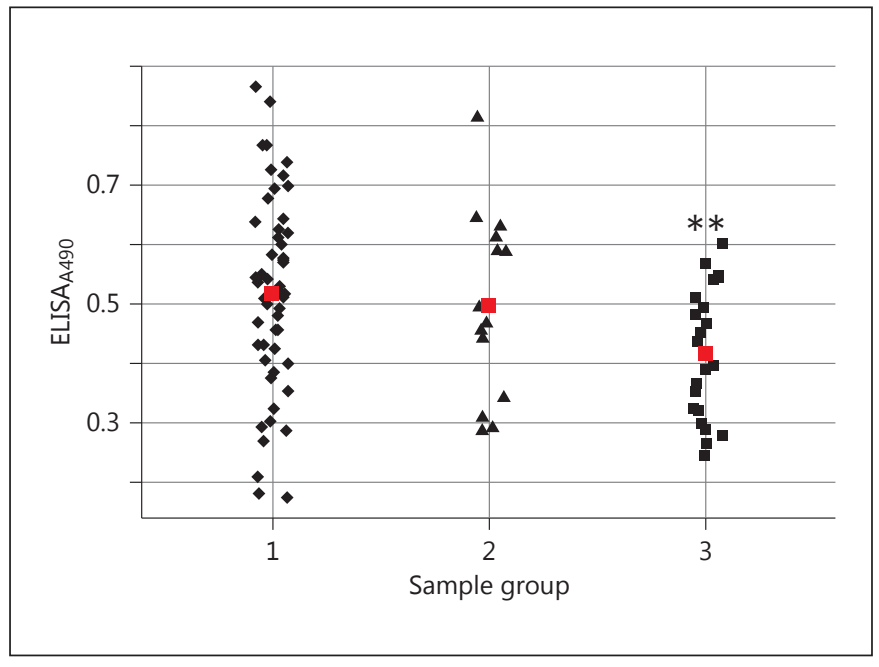

Fig. 1. Serological reactivity of human sera against G. applanatum crude spore cytoplasmic extract when tested with an indirect ELISA $\left(\mathrm{A}_{490}\right)$. The $x$ axis represents the 3 groups (group 1, $n=51$; group 2, $n=14$; and group 3, $n=22$ ) of different allergic profiles and the $y$ axis the mean $\mathrm{A}_{490}$ for each individual. The red square within each group represents the group mean. Color refers to the online version only. ${ }^{* *}$ The mean difference was statistically significant $(p<0.05)$ compared to group 1.

nificant difference $(p=0.04)$ in the mean $\mathrm{A}_{490}$ between the 3 groups. After performing a Bonferroni pairwise comparison, the mean $\mathrm{A}_{490}$ was statistically significantly higher only when group 1 was compared to group 3 ( $p=$ $0.03)$. However, no statistically significant mean differences were found between group 1 and group $2(p=1.00)$ or between group 2 and group $3(p=0.37)$. Positive and negative control sera mean $\mathrm{A}_{490}$ values were 0.6240 and 0.2885 , respectively. These results suggest that the group with an allergic history, based on SIgE to commercial extracts, was more reactive to the CSCE than the group with no reported history of allergies (based on self-reported symptomatology).

\section{Three out of Five Serum Samples from Group 1 Were}

Reactive to CSCE in the WB

In order to visualize IgE-binding polypeptides present in CSCE, WB were performed with individual serum samples from group 1 . We used sera from group 1 because they demonstrated the highest reactivity to CSCE in indirect ELISA compared to the other 2 groups, and they had allergic sensitization to 1 or more allergens as demonstrated by RAST. Sixty-five percent (33/51) of individuals were reactive to 1 or more polypeptide bands (Table 3 ). Reactivity against the IgE-binding polypeptides

IgE-Binding Polypeptides of Ganoderma applanatum
Table 3. Western blot reactivity among serum samples from group $1(n=51)$

\begin{tabular}{llll}
\hline $\begin{array}{l}\text { Western } \\
\text { blot reactivity }\end{array}$ & $\begin{array}{l}\text { Reactive poly- } \\
\text { peptide bands, } n\end{array}$ & $\begin{array}{l}\text { Reactive } \\
\text { serum samples, } n\end{array}$ & $\begin{array}{l}\text { Total } \\
\text { sera, } n\end{array}$ \\
\hline Reactive & 1 & 3 & 33 \\
& 2 & 19 & \\
& 3 & 6 & 18 \\
\hline Nonreactive & 0 & 5 & 18 \\
\hline
\end{tabular}

Table 4. Percentage of reactivity to immunoglobulin E-binding polyleptides among the 33 reactive serum samples in the Western blot

\begin{tabular}{|c|c|c|}
\hline $\begin{array}{l}\text { Molecular mass of the } \\
\text { immunoglobulin } \\
\text { E-binding polypeptide, } \\
\mathrm{kDa}\end{array}$ & Reactivity, \% & $95 \% \mathrm{CI}$ \\
\hline 19 & 6.1 & $0.7-20.2$ \\
\hline 24 & 3.0 & $0.1-15.8$ \\
\hline 33 & 18.2 & $7.0-34.5$ \\
\hline 45 & 24.2 & $11.1-42.3$ \\
\hline 56 & 87.9 & $71.8-96.6$ \\
\hline 75 & 3.0 & $0.1-15.8$ \\
\hline 81 & 97.0 & $84.2-99.9$ \\
\hline
\end{tabular}

Bold numbers represent the statistically significant proportions, as determined with a Fisher's exact test, of serological reactivity in the Western blot.

was confirmed via image analysis based on the presence of the respective corresponding peaks in the membrane plots generated with the software Image ${ }^{\circledR}$. Seven IgEbinding polypeptides were detected in a variety of MW (i.e., 19, 24, 33, 45, 56, 75, and $81 \mathrm{kDa}$; Fig. 2). The positive control serum was reactive to the polypeptide band of approximately $45 \mathrm{kDa}$, whereas the negative control showed no reactivity. These results further support the reactivity of the CSCE as seen earlier with the indirect ELISA.

\section{The 56- and 81-kDa IgE-Binding Polypeptides Had} the Highest Proportion of Reactivity

To determine the IgE-binding polypeptides with the highest reactivity among the 33 reactive serum samples from group 1, Fisher's exact test was performed to compare the proportion of reactive serum samples against each IgE-binding polypeptide. As shown in Table 4, the

Int Arch Allergy Immunol 2017;172:139-149 143 


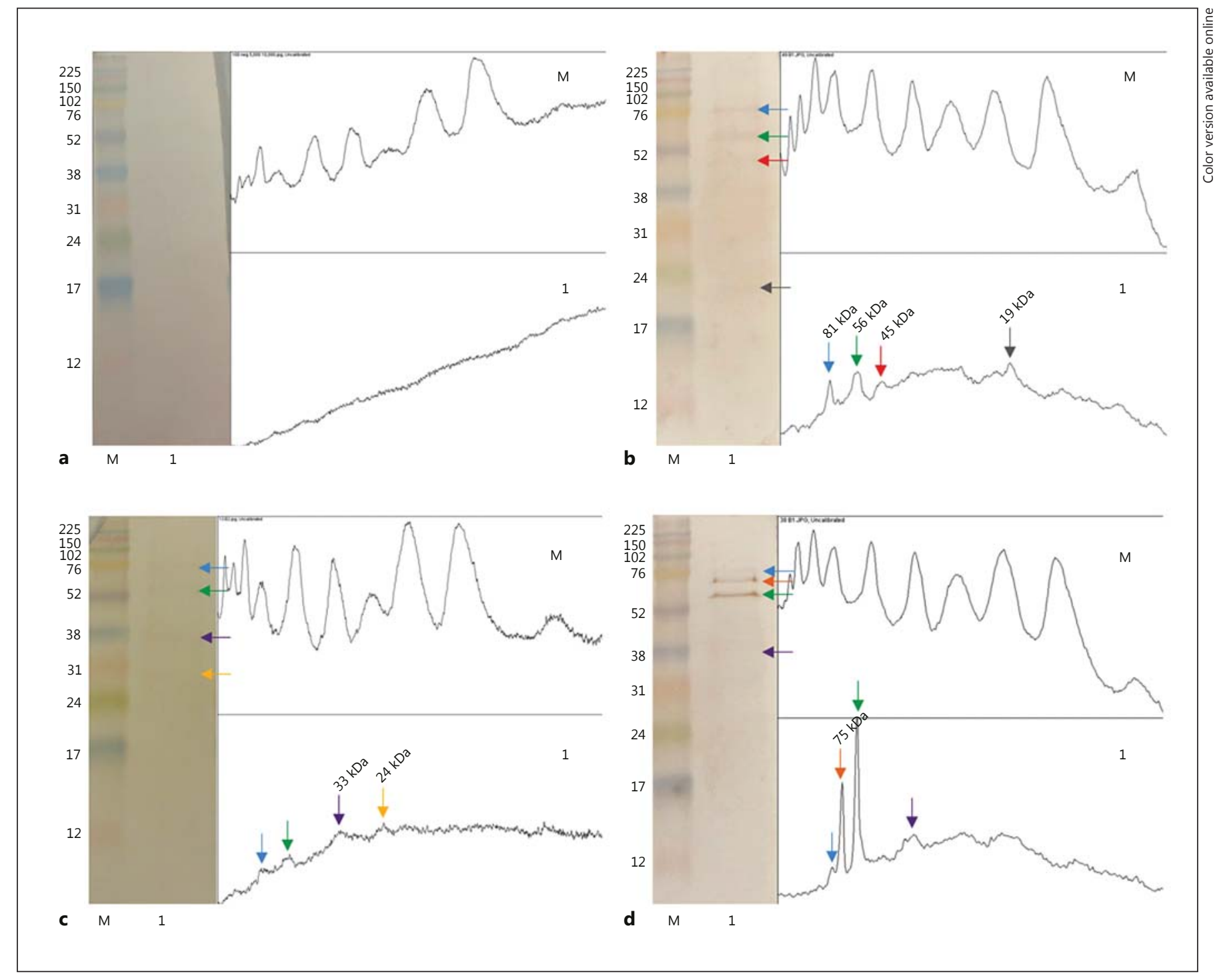

Fig. 2. Plots of the serum samples in which the 7 immunoglobulin E (IgE)-binding polypeptides, and their corresponding molecular weights, were immunodetected by Western blot. Each band is represented by arrows of different colors and their corresponding molecular weight. a Negative serum sample. b Serum sample immunoreactive to the $81-\mathrm{kDa}$ (blue arrow), the $56-\mathrm{kDa}$ (green arrow), the $45-\mathrm{kDa}$ (red arrow), and the $19-\mathrm{kDa}$ (grey arrow) IgE-binding polypeptides. c Serum sample immunoreactive to the $33-\mathrm{kDa}$ (purple arrow) and $24-\mathrm{kDa}$ (yellow arrow) IgE-binding polypeptides. d Serum sample immunoreactive to the $75-\mathrm{kDa}$ (orange arrow) IgE-binding polypeptide. $\mathrm{M}$, markers; 1 , lane 1 . Colors refer to the online version only. proportion of reactivity was highest for the $56-\mathrm{kDa}$ (87.9\%; 95\% CI 71.8-96.6) and 81-kDa (97.0\%; 95\% CI 84.2-99.9) IgE-binding polypeptides.

\section{There Was No Association between Indirect ELISA $A_{490}$ and WB Reactivity}

To evaluate if there was an association between indirect ELISA $\mathrm{A}_{490}$ and $\mathrm{WB}$ reactivity, indirect ELISA values were grouped by WB reactivity among group 1 serum samples (i.e., reactive to one or more IgE-binding polypeptides or not reactive at all; Fig. 3). Although group 1 reactive serum samples had a higher mean $\mathrm{A}_{490}(0.5285 \pm$ $0.1658)$ than the nonreactive serum samples $(0.4922 \pm$ 0.1617 ), the mean difference was not statistically significant $(p=0.45)$ after performing a 2 -tailed Student $t$ test (assuming equal variance). Therefore, the reactivity of the 


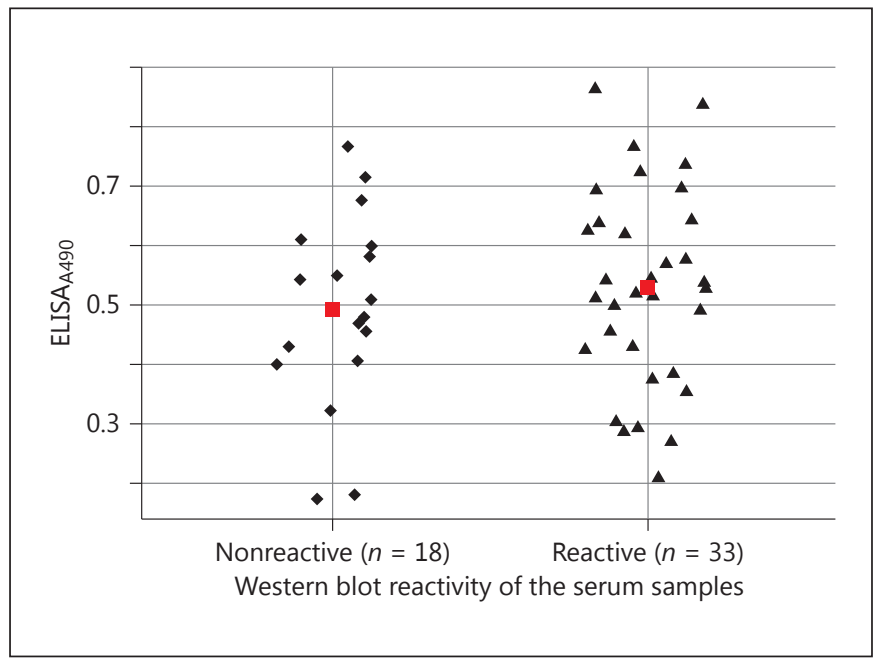

Fig. 3. Comparison of group 1 indirect ELISA $A_{490}$ between nonreactive $(n=18)$ and reactive $(n=33)$ individuals in Western blot. The $x$ axis represents Western blot reactivity and the $y$ axis the mean $\mathrm{A}_{490}$ for each individual. The red square within each group represents the group mean. Color refers to the online version only.

serum samples in the indirect ELISA was not associated with their reactivity in the WB.

\section{MS Analysis Putatively Identified 3 IgE-Binding}

Polypeptides as Basidiomycete-Derived Enzymes

The 3 IgE-binding polypeptides with the highest reactivity in $\mathrm{WB}$, with an approximate $\mathrm{MW}$ of $81 \mathrm{kDa}(\mathrm{P} 1)$, $56 \mathrm{kDa}(\mathrm{P} 2)$, and $45 \mathrm{kDa}(\mathrm{P} 3)$, were analyzed via MS for a putative identification. The identification for each polypeptide, along with information derived from the Mascot reports, is listed in Table 5. Reports were interpreted for the best hit based on the highest protein score which also matched the polypeptides' approximate MW. This resulted in selection of the protein hit with the third highest protein score for $\mathrm{P} 1$ and the protein hits with the highest protein score for $\mathrm{P} 2$ and $\mathrm{P} 3$, all being basidiomycetederived enzymes.

\section{Discussion}

In this study, the serological reactivity of the Puerto Rican population to G. applanatum CSCE was evaluated. Serum samples from allergic individuals with sIgE against commercial extracts (group 1), no sIgE to commercial extracts (group 2), or no self-reported history of allergies (group 3) were tested with indirect ELISA and WB. Indi-

IgE-Binding Polypeptides of Ganoderma applanatum rect ELISA revealed that serological reactivity was higher among individuals from group 1 , and further evaluation of this group with WB yielded a serological reactivity prevalence above $60 \%$. MS revealed that the IgE-binding polypeptides with the highest serological reactivity were enzymes with metabolic properties. This study provides further evidence of the allergenic potential of airborne basidiospores endemic in tropical settings, such as those from G. applanatum.

Seven G. applanatum CSCE IgE-binding polypeptides were detected in WB, with MW ranging from 19 to 81 $\mathrm{kDa}$. Two of them, with approximate MW of $81 \mathrm{kDa}(\mathrm{P} 1)$ and $56 \mathrm{kDa}(\mathrm{P} 2)$, had the highest proportions of reactivity, i.e., 97.0 and $87.9 \%$, respectively. These results are similar to the results of the study by Vijay et al. [20], in which they found $8 \mathrm{G}$. applanatum spore allergens in a comparable MW range (18-82 kDa). To our knowledge, this is the only previous study identifying G. applanatum spore IgE-binding polypeptides. Even though no sensitization prevalence was reported by the authors (only 3 atopic patients were studied), a strong reactivity of sIgE antibodies was observed at 6 different MW. These reactivities included one at approximately $82 \mathrm{kDa}$ and the strongest at approximately $45 \mathrm{kDa}$. Interestingly, this last IgE-binding polypeptide has the same approximate MW as one reported in this study (P3), which also had one of the highest reactivities. These allergenic components recognized by the majority of sensitized individuals could eventually be considered markers in cases of fungal allergy. Differences in the allergenic polypeptides detected between the studies may arise from the different extraction protocols, the population tested (possibly sensitized to different allergenic components), or intrinsic allergen spore differences between places, as it has been demonstrated that spore extracts from different locations can vary [21-25].

MS analysis of P1, P2, and P3 putatively identified these 3 polypeptides as metabolic enzymes derived from fungal species belonging to the Basidiomycota division, the same as G. applanatum. Aconitate hydratase and enolase are involved in cellular metabolic pathways, while catalase is part of the oxidative stress response proteins (Table 5). It is not uncommon to see proteins involved in intrinsic cellular metabolic pathways acting simultaneously as allergens, and they have been described for fungi in both categories [26]. Each one of the enzymes has also been described as an allergen for different species. For instance, aconitate hydratase has been reported as an allergen of the Asian wasp's venom, and proteins with catalase and enolase activity have been identified as fungal

Int Arch Allergy Immunol 2017;172:139-149 145 
Table 5. Putative identification of IgE-binding polypeptides by mass spectrometry from the National Center for Biotechnology Information database using other Fungi taxonomies

\begin{tabular}{|c|c|c|c|}
\hline & \multicolumn{3}{|l|}{ Polypeptide band } \\
\hline & $1(81 \mathrm{kDa})$ & $2(56 \mathrm{kDa})$ & $3(45 \mathrm{kDa})$ \\
\hline NCBI accession No. & 2::gi|170094674 & 2::gi|754378673 & 2::gi|630186999 \\
\hline Protein name & $\begin{array}{l}\text { Aconitate } \\
\text { hydratase }\end{array}$ & $\begin{array}{l}\text { Hypothetical protein } \\
\text { PHLGIDRAFT_83711 }\end{array}$ & Enolase \\
\hline Species & $\begin{array}{l}\text { Laccaria bicolor } \\
\text { S238N-H82 }\end{array}$ & $\begin{array}{l}\text { Phlebiopsis gigantea } \\
\text { 11061_1 CR5-6 }\end{array}$ & $\begin{array}{l}\text { Moniliophthora roreri } \\
\text { MCA } 2997\end{array}$ \\
\hline Biological function & $\begin{array}{l}\text { Reversible } \\
\text { isomerization of } \\
\text { citrate } \\
\text { and isocitrate as part } \\
\text { of the tricarboxylic } \\
\text { acid (Krebs) cycle }\end{array}$ & $\begin{array}{l}\text { Putative catalase } \\
\text { function (Hori et al. } \\
\text { [42]): decomposition } \\
\text { of hydrogen peroxide } \\
\text { to molecular oxygen } \\
\text { and water; inorganic } \\
\text { ion transport and } \\
\text { metabolism }\end{array}$ & $\begin{array}{l}\text { Reversible dehydration } \\
\text { of 2-phospho-D- } \\
\text { glycerate to } \\
\text { phosphoenolpyruvate } \\
\text { as part of the glycolytic } \\
\text { and gluconeogenesis } \\
\text { pathways }\end{array}$ \\
\hline Cellular location & Mitochondria & Unknown & Cytoplasm \\
\hline Protein score & 206 & 1,141 & 1,030 \\
\hline Molecular weight, $\mathrm{Da}$ & 82,919 & 57,439 & 47,270 \\
\hline Isoelectric point & 6.02 & 6.39 & 5.65 \\
\hline Peptide numbers matching to the protein & 10 & 28 & 37 \\
\hline Significant peptide numbers matching to the protein & 10 & 28 & 37 \\
\hline Unique peptide numbers to the protein & 3 & 2 & 8 \\
\hline Unique peptide numbers to the protein with significance & 3 & 2 & 8 \\
\hline Protein sequence coverage & 4.2 & 5.9 & 19.1 \\
\hline emPAI & 0.26 & 0.18 & 2.03 \\
\hline Molar \% ${ }^{\mathrm{a}}$ & 14.61 & 2.679 & 9.107 \\
\hline
\end{tabular}

emPAI, exponentially modified protein abundance index $=10^{\mathrm{PAI}}-1$, where PAI is defined as the number of detected peptides divided by the number of observable peptides per protein and has a linear relationship to the logarithm of protein concentration in LCMS/MS experiments, making emPAI proportional to the protein content in a protein mixture (Ishihama et al. [43]).

${ }^{\mathrm{a}} \mathrm{emPAI} / \Sigma(\mathrm{emPAI}) \times 100$.

allergens in several fungal genera, including Aspergillus and Penicillium [27-30]. In fact, enolases are known to be a class of highly conserved fungal allergens and major allergens of prominent fungal species inducing type I allergy such as $C$. herbarum and $A$. alternata [31, 32]. Identification of metabolic enzymes as prevalent allergens in G. applanatum might suggest that these enzymes can be allergen sources in other basidiomycete species as well.

WB of G. applanatum CSCE with individuals from group 1 resulted in more than $60 \%$ of the reactive serum samples having sIgE antibodies towards one or more spore polypeptides. A high prevalence of sensitization to these basidiospores could be the result of certain attributes which make G. applanatum a good allergen source. The fruiting bodies are present all year long in different areas of Puerto Rico, as evidenced by the presence of basidiocarps in different municipalities throughout the is- land in any season, in both urban and forested scenarios. In turn, each basidiocarp can potentially release trillions of spores daily, causing exposure of spore allergens to individuals in clinically relevant amounts, a prerequisite for the development of allergic sensitization to an allergen source $[5,7,33]$. Even if the basidiospore source is not close to populated areas, the spores can still reach urban places by wind dispersion, as demonstrated by the daily reports at the San Juan Station certified by the National Allergy Bureau of the American Academy of Allergy Asthma and Immunology (http://pollen.aaaai.org/nab/ index.cfm? $\mathrm{p}=$ allergenreport\&stationid=168). Continuous breathing of high numbers of spores results in $\mathrm{IgE}$ development towards spore antigens in susceptible individuals; therefore, it is not surprising to see a considerable proportion of reactivity to G. applanatum among the individuals evaluated in the study $[5,12,24]$. These results 
suggest that fungal allergens not routinely tested in diagnostic panels, like those from G. applanatum spores, should be considered among the panels of allergens for skin and serological testing in tropical settings.

The higher reactivity in the indirect ELISA for individuals with sIgE to commercial extracts (group 1) compared to group 3, but not to group 2, was expected because individuals from both group 1 and group 2 had a suspected allergic symptomatology (due to medical referrals for sIgE testing). The higher reactivity in individuals from group 1 compared to group 2, though not statistically significant, matches our expectations because many fungi-sensitized individuals have sIgE to other allergen sources as well, including inhalant allergens [33]. Sensitivity to simultaneous inhalant allergens has been reported in SPT with G. applanatum antigen preparations, in which $96.7 \%$ of positive subjects were also positive to other common inhalant allergen sources [34]. The reactivity of individuals from group 2 in the indirect ELISA, which reported results between the reactivity of individuals with sIgE to commercial extracts and those with no self-reported history of allergic symptoms, suggests that testing basidiomycetes' allergens in Puerto Rico could be important in establishing an allergy diagnosis.

There was no relationship between the serological reactivity of individuals from group 1 in the indirect ELISA and the WB. Since the same extract pool was used for both assays, variability in the extract composition and/or proportion of allergens because of fungal strain or batch-tobatch differences was discarded [3]. A possible reason may be the nature of the antigen source, as discrepancies have been reported concerning the sensitivity and specificity of ELISA tests when crude extracts are used [35]. Spore crude extracts are known to contain a mixture of proteins and other spore nonprotein components, like carbohydrates [22]. Within the extract, these components can intercompete for attachment sites or form interactions that prevent binding of other molecules [35, 36]. These interferences of molecular nature, which are not present in WB, might have an effect on the sensitivity and specificity of the ELISA [36]. Furthermore, there might be a difference in the antigenicity of some native proteins compared to their denatured counterparts in the $\mathrm{WB}$, as alteration of the structure of antigenic epitopes might alter serological and other immunological analyses of a protein [23, 37, 38].

The small number of serum samples must be considered a limiting factor in the current study. Another limitation was not having all serum samples tested with RAST for the same battery of commercial allergen ex-

IgE-Binding Polypeptides of Ganoderma applanatum tracts, and the lack of a more thorough clinical history of volunteers. This information may have allowed us to perform additional statistical analyses to examine the possibility of cross-reactivity or the relationship with other health factors. Because this was a pilot study, we did not expect to have a large sample size or complete a comprehensive clinical history. As a follow-up to this investigation, a clinical study recruiting patients from the UPRMSC Allergy Clinics is under way, in which full clinical profiles for each individual will be available. The lack of protease inhibitors in the CSCE preparation may have influenced the extract reactivity due to a possible proteolytic degradation of allergens or alteration in their IgEbinding sites, but measures were taken to reduce this limitation (i.e., maintaining the extract at lower temperatures) [22, 23]. Protease inhibitors were not added because some proteins require proteolytic activation to exhibit their allergenic potential [22, 39]. Reactivity could also have been influenced by other factors, such as diminished allergen recovery from the spores, the possibility of G. applanatum allergenic components having a lower sensitization capacity, or interindividual variability in the immune responses [23, 33, 34]. Finally, the use of one-dimensional immunoblotting for the identification of CSCE IgE-binding polypeptides is a limitation for 2 reasons: first, reactive bands may contain more than 1 polypeptide with the same MW and, second, differences in antibody reactivity between protein isoforms, if any, are masked $[40,41]$. Due to a lack of resources, 2-dimensional immunoblotting was not possible. Prospective studies will employ 2-dimensional immunoblotting, complemented with MS analysis, to confirm the identity of the IgE-binding polypeptides putatively identified in this study.

In conclusion, this study provides evidence of the serological reactivity of Puerto Rican individuals to G. applanatum spore allergens. Also, the findings of this study support previous studies from our group about the allergenic potential of less-studied fungi, such as those from basidiomycetes [5-7]. The 3 most recognized allergens among CSCE-sensitized individuals have been putatively identified; however, confirmation of each polypeptide's identity along with their subsequent purification is needed for proper immunological/molecular characterization and assessment of clinical relevance. This is the first step towards the formulation of high-quality G. applanatum allergen sources for use in allergy diagnostic tools, as well as in prevention strategies (i.e., vaccines) and allergenspecific immunotherapy in the tropics, including Puerto Rico.

Int Arch Allergy Immunol 2017;172:139-149 DOI: $10.1159 / 000455254$ 


\section{Acknowledgements}

We would like to acknowledge the Associate Deanship of Biomedical Affairs of the School of Medicine of the UPR-MSC for their financial support. We thank Dr. Edna Aquino for her contribution in drawing blood from volunteer subjects. In addition, we are grateful to Lic. Ilia Toledo from the Toledo Clinical Laboratory in Arecibo, PR, USA, for kindly donating the sera remnants used in this project, and Dr. Sylvette Nazario from the UPR-MSC Allergy Clinics for performing the SPT. We are grateful to Dr. Deborah Jean Lodge from the International Institute of Tropical Forestry, San Juan, PR, USA, for her assistance in the search and identification of G. applanatum fruiting bodies and spores, and the staff of El Verde Field Station, UPR, for their assistance in the search of G. applanatum fruiting bodies and spore print collection at that location. Finally, we thank the volunteers who kindly donated their blood for serum extraction used in this study and/or aided in the search of G. applanatum fruiting bodies and spore print collection. Partial infrastructure support was provided by NIMHD-RCMI Program G12-MD-007600 at the UPR Medical Sciences Campus, and the Puerto Rico Clinical and Translational Research Consortium under NIH award No. 2U54MD007587-04. The content is solely the responsibility of the authors and does not necessarily represent the official views of the National Institutes of Health.

\section{Disclosure Statement}

The authors certify that they have no affiliations with or involvement in any organizations or entity with any financial, or nonfinancial, interest in the subject matter or materials discussed in this paper.

\section{References}

1 Craig RL, Levetin E: Multi-year study of Ganoderma aerobiology. Aerobiologia 2000; 16:75-81.

2 Helbling A, Brander KA, Horner WE, Lehrer $\mathrm{SB}$ : Allergy to basidiomycetes. Chem Immunol 2002;81:28-47.

3 Simon-Nobbe B, Denk U, Poll V, Rid R, Breitenbach M: The spectrum of fungal allergy. Int Arch Allergy Immunol 2008;145:58-86.

4 Quintero E, Rivera-Mariani F, Bolaños-Rosero B: Analysis of environmental factors and their effects on fungal spores in the atmosphere of a tropical urban area (San Juan, Puerto Rico). Aerobiologia 2010;26:113-124.

5 Rivera-Mariani FE, Bolaños-Rosero B: Allergenicity of airborne basidiospores and ascospores: need for further studies. Aerobiologia 2012;28:83-97

6 Rivera-Mariani FE, Nazario-Jimenez S, Lopez-Malpica F, Bolaños-Rosero B: Sensitization to airborne ascospores, basidiospores, and fungal fragments in allergic rhinitis and asthmatic subjects in San Juan, Puerto Rico. Int Arch Allergy Immunol 2011;155:322-334.

7 Rivera-Mariani FE, Nazario-Jimenez S, Lopez-Malpica F, Bolaños-Rosero B: Skin test reactivity of allergic subjects to basidiomycetes' crude extracts in a tropical environment. Med Mycol 2011;49:887-891.

8 Almaguer M, Aira MJ, Rodriguez-Rajo FJ, Fernandez-Gonzalez M, Rojas-Flores TI: Thirty-four identifiable airborne fungal spores in Havana, Cuba. Ann Agric Environ Med 2015;22:215-220.

9 Calderon C, Lacey J, McCartney HA, Rosas I: Seasonal and diurnal variation of airborne basidiomycete spore concentrations in Mexico City. Grana 1995;34:260-268.

10 Almaguer M, Rojas-Flores TI, Rodríguez-Rajo FJ, Aira M-J: Airborne basidiospores of $\mathrm{Co}$ prinus and Ganoderma in a Caribbean region. Aerobiologia 2014;30:197-204.
11 Horner WE, Helbling A, Lehrer SB: Basidiomycete allergens. Allergy 1998;53:1114-1121. 12 Levetin E, Horner WE, Scott JA; Environmental Allergens Workgroup: taxonomy of allergenic fungi. J Allergy Clin Immunol Pract 2016;4:375-385.

13 World Health Organization and International Union of Immunological Societies Allergen Nomenclature Sub-Committee: Allergen nomenclature. http://allergen.org/search. php? TaxSource=Fungi\%20Basidiomycota.

14 Agarwal R, Gupta D: Severe asthma and fungi: current evidence. Med Mycol 2011;49 (suppl 1):S150-S157.

15 Lambrecht BN, Hammad H: Allergens and the airway epithelium response: gateway to allergic sensitization. J Allergy Clin Immunol 2014;134:499-507.

16 Cohen RT, Canino GJ, Bird HR, Shen S, Rosner BA, Celedon JC: Area of residence, birthplace, and asthma in Puerto Rican children. Chest 2007;131:1331-1338.

17 Bartolomei-Diaz JA, Amill-Rosario A, Claudio L, Hernandez W: Asthma mortality in Puerto Rico: 1980-2007. J Asthma 2011;48:202-209.

18 Figueroa-Santiago O, Delgado B, Espino AM: Fasciola hepatica saposin-like protein-2 based ELISA for the serodiagnosis of chronic human fascioliasis. Diagn Microbiol Infect Dis 2011;70:355-361.

19 Laemmli UK: Cleavage of structural proteins during the assembly of the head of bacteriophage T4. Nature 1970;227:680-685.

20 Vijay HM, Comtois P, Sharma R, Lemieux R: Allergenic components of Ganoderma applanatum. Grana 1991;30:167-170.

21 Liengswangswong V, Salvaggio JE, Lyon FL, Lehrer SB: Basidiospore allergens - determination of optimal extraction methods. Clin Allergy 1987;17:191-198.

22 Horner WE, Helbling A, Salvaggio JE, Lehrer SB: Fungal allergens. Clin Microbiol Rev 1995;8:161-179.
23 Horner WE, Levetin E, Lehrer SB: Basidiospore allergen release: elution from intact spores. J Allergy Clin Immunol 1993;92:306312.

24 Cutten AE, Hasnain SM, Segedin BP, Bai TR, McKay EJ: The basidiomycete Ganoderma and asthma: collection, quantitation and immunogenicity of the spores. NZ Med J 1988; 101:361-363.

25 Horner WE, Helbling A, Lehrer SB: Basidiomycete allergens: comparison of three Ganoderma species. Allergy 1993;48:110-116.

26 Denning DW, O’Driscoll BR, Hogaboam CM, Bowyer P, Niven RM: The link between fungi and severe asthma: a summary of the evidence. Eur Respir J 2006;27:615-626.

27 Benndorf D, Müller A, Bock K, Manuwald O, Herbarth O, von Bergen M: Identification of spore allergens from the indoor mould Aspergillus versicolor. Allergy 2008;63:454-460.

28 Sookrung N, Wong-din-Dam S, Tungtrongchitr A, Reamtong O, Indrawattana N, Sakolvaree Y, Visitsunthorn N, Manuyakorn W, Chaicumpa W: Proteome and allergenome of Asian wasp, Vespa affinis, venom and IgE reactivity of the venom components. J Proteome Res 2014;13:1336-1344.

29 Chiu LL, Lee KL, Lin YF, Chu CY, Su SN, Chow LP: Secretome analysis of novel IgEbinding proteins from Penicillium citrinum. Proteomics Clin Appl 2008;2:33-45.

30 Lai HY, Tam MF, Tang RB, Chou H, Chang CY, Tsai JJ, Shen HD: cDNA cloning and immunological characterization of a newly identified enolase allergen from Penicillium citrinum and Aspergillus fumigatus. Int Arch Allergy Immunol 2002;127:181-190.

31 Breitenbach M, Simon B, Probst G, Oberkofler H, Ferreira F, Briza P, Achatz G, Unger A, Ebner C, Kraft D, Hirschwehr R: Enolases are highly conserved fungal allergens. Int Arch Allergy Immunol 1997;113:114-117. 
32 Simon-Nobbe B, Probst G, Kajava AV, Oberkofler H, Susani M, Crameri R, Ferreira F, Ebner $\mathrm{C}$, Breitenbach M: IgE-binding epitopes of enolases, a class of highly conserved fungal allergens. J Allergy Clin Immunol 2000;106: 887-895.

33 Twaroch TE, Curin M, Valenta R, Swoboda I: Mold allergens in respiratory allergy: from structure to therapy. Allergy Asthma Immunol Res 2015;7:205-220.

34 Tarlo SM, Bell B, Srinivasan J, Dolovich J, Hargreave FE: Human sensitization to Ganoderma antigen. J Allergy Clin Immunol 1979; 64:43-49.

35 Kenny GE, Dunsmoor CL: Principles, problems, and strategies in the use of antigenic mixtures for the enzyme-linked immunosorbent assay. J Clin Microbiol 1983;17:655-665.

36 Rauch P, Zellmer A, Dankbar N, Specht C, Sperling D: Optimisation of assays: interference in immunoassays: recognize and avoid. Laborwelt 2005;6:2-7.

37 Wang M, Tzeng T-Y, Fung C-Y, Ou W-C, Tsai R-T, Lin C-K, Tsay GJ, Chang D: Human
anti-JC virus serum reacts with native but not denatured JC virus major capsid protein VP1. J Virol Methods 1999;78:171-176.

38 Ipsen H, Larson J: Detection of antigen-specific IgE antibodies in sera from allergic patients by SDS-PAGE immunoblotting and crossed radioimmunoelectrophoresis; in Heegaard N (ed): Handbook of Immunoblotting of Proteins. Boca Raton, CRC Press, 1988, pp 164-165.

39 Wongtim S, Lehrer SB, Salvaggio JE, Horner WE: Protease activity in cockroach and basidiomycete allergen extracts. Allergy Proc 1993; 14:263-268.

40 Barea PL, Calvo E, Rodriguez JA, Rementeria A, Calcedo R, Sevilla MJ, Ponton J, Hernando FL: Characterization of Candida albicans antigenic determinants by two-dimensional polyacrylamide gel electrophoresis and enhanced chemiluminescence. FEMS Immunol Med Microbiol 1999;23:343-354.

41 Kukreja N, Singh BP, Arora N, Gaur SN, Sridhara S: Identification of Epicoccum purpurascens allergens by two-dimensional immu- noblotting and mass spectrometry. Immunobiology 2008;213:65-73.

42 Hori C, Ishida T, Igarashi K, Samejima M, Suzuki H, Master E, Ferreira P, Ruiz-Dueñas FJ, Held B, Canessa P, Larrondo LF, Schmoll M, Druzhinina IS, Kubicek CP, Gaskell JA, Kersten P, St John F, Glasner J, Sabat G, Splinter BonDurant S, Syed K, Yadav J, Mgbeahuruike AC, Kovalchuk A, Asiegbu FO, Lackner G, Hoffmeister D, Rencoret J, Gutiérrez A, Sun H, Lindquist E, Barry K, Riley R, Grigoriev IV, Henrissat B, Kües U, Berka RM, Martínez AT, Covert SF, Blanchette RA, Cullen D: Analysis of the Phlebiopsis gigantea genome, transcriptome and secretome provides insight into its pioneer colonization strategies of Wood. PLoS Genet 2014;10:e1004759.

43 Ishihama Y, Oda Y, Tabata T, Sato T, Nagasu T, Rappsilber J, Mann M: Exponentially modified protein abundance index (emPAI) for estimation of absolute protein amount in proteomics by the number of sequenced peptides per protein. Mol Cell Proteomics 2005;4: 1265-1272. 